\title{
Electrochemical Quantitative Assessment of Labetalol Hydrochloride in Pure Form and Combined Pharmaceutical Formulations
}

\author{
Maissa Yacoub Salem, ${ }^{1}$ Nagiba Yehia Hassan, ${ }^{1}$ Yasmin Mohamed Fayez, \\ Samah Abd ELSabour Mohamed ${ }^{2}$ and Enas Shabaan Ali ${ }^{2}{ }^{*}$ \\ ${ }^{1}$ Analytical chemistry department- Faculty of Pharmacy, Cairo University. Kasr-El-Aini 11562-Cairo, Egypt \\ ${ }^{2}$ National Organization for Drug Control and Research (NODCAR).Giza, Egypt \\ *Corresponding author: E-mail: enas83ali@gmail.com \\ Tel.: +201008836585
}

Received: 04-26-2019

\begin{abstract}
This work describes how to utilize the electrochemical technique to determine labetalol hydrochloride (Lab) in pure form and combined pharmaceutical formulation for quality control purposes. Four membrane sensors were developed using two plasticizers, dioctyl phthalate with 2-hydroxypropyl- $\beta$-cyclodextrin and ammonium reineckate (RNC) for sensors $1 \mathrm{a}$ and $2 \mathrm{a}$, and tributyl phthalate with 2-hydroxypropyl- $\beta$-cyclodextrin and ammonium reineckate for sensors $1 \mathrm{~b}$ and $2 \mathrm{~b}$ as ionophores in polyvinyl chloride (PVC) matrix. Fast response and stable Nernstian slopes of 59.60, 57.58, 53.00 and $55.00 \mathrm{mV} /$ decade for sensors $1 \mathrm{a}, 2 \mathrm{a}, 1 \mathrm{~b}$, and $2 \mathrm{~b}$, respectively, were obtained by developed sensors within a concentration range $10^{-4} \mathrm{M}-10^{-2} \mathrm{M}$ over $\mathrm{pH}$ range 2.00-5.10. Developed sensors showed good selectivity for Lab in pure form, in the presence of co-administered drugs, many of interfering ions, and excipients present in pharmaceutical formulation. No remarkable difference was detected upon the statistical comparison between the results of proposed sensors and the official method.
\end{abstract}

Keywords: Ammonium reineckate; 2-hydroxypropyl- $\beta$-cyclodextrin; ion-selective electrode; labetalol hydrochloride; tributyl phthalate; dioctyl phthalate.

\section{Introduction}

Labetalol hydrochloride (Lab), Fig (1), known chemically as 5-[1-hydroxy-2-[(1-methyl-3-phenylpropyl)-amino]-ethyl]-salicylamide monohydrochloride, ${ }^{1}$ is a mixed $\alpha$ - and $\beta$-adrenoceptor blocking agent that works by blocking the action of epinephrine on heart and blood vessels. It is considered one of the major therapeutic drugs for the treatment of hypertension either alone or combined with other antihypertensive drugs or diuretics. It is also used to induce hypotension during surgery as Lab reduces blood pressure more rapidly than other $\alpha$ - or $\beta$-receptor blockers. Lab is a well-known doping agent in sports and hence has been banned for Olympic players by the International Olympic Committee. ${ }^{2-4}$

Literature survey revealed that various analytical techniques were employed to estimate the concentration of Lab in pharmaceutical preparations, either alone or in combination with hydrochlorothiazide, and in biological fluids. These techniques include spectrofluorimetry, ${ }^{5-10}$ chromatography, ${ }^{11-18}$ capillary electrophoresis, ${ }^{19,20}$ capillary isotachophoresis, ${ }^{21} \mathrm{NMR}$ spectroscopy, ${ }^{22}$ ion-selective electrode using ion-pair complex, ${ }^{23}$ and adsorptive voltammetry, ${ }^{24}$ methods which in comparison to proposed electrodes require sample manipulation, are affected by various interferences, inappropriate for colored or turbid solutions, and more expensive as they require sophisticated equipment and software for data processing.

Ion-selective electrode (ISE) as a new analytical technique offers an accurate quantitative estimation of active drug substance in pharmaceutical formulation regardless of turbidity or color of sample media due to its relatively high selectivity which is determined by the nature and composition of the membrane materials used in the fabrication of the electrode. ${ }^{25}$ 
<smiles>CC(CCc1ccccc1)NCC(O)c1ccc(O)c(C(N)=O)c1</smiles>

Fig. 1. Chemical structure of labetalol hydrochloride

This work describes the advantage of utilization of ion-selective sensors prepared in PVC matrix using 2-hydroxypropyl- $\beta$-cyclodextrin and ammonium reineckate (RNC) with two different plasticizers for the determination of Lab in pure form and combined pharmaceutical formulation having equal efficiency as the previously developed spectrophotometric and HPLC methods, ${ }^{10,18}$ with superiority of elimination of sample pretreatment, working over wide $\mathrm{pH}$ range, devoid of several preparation steps as in HPLC and being eco-friendly.

\section{Experimental}

\section{1. Apparatus}

- $\mathrm{pH}$ meter $3510 \mathrm{pH} / \mathrm{mV} /{ }^{\circ} \mathrm{C}$ (Jenway, UK)

- $\mathrm{pH}$ glass electrode (Jenway, UK)

- $\mathrm{Ag} / \mathrm{AgCl}$ double junction reference electrode (Jenway, UK)

- 5-digit electronic balance model XA60/220 (RADWAG, Poland)

- water purification system (Milli Q, France)

- magnetic stirrer: model 34532 (Snijders, Holland)

- thermometer

- sonicator (Falc, Japan)

\section{2. Samples and Pharmaceutical Formulations}

- Pure labetalol hydrochloride was kindly supplied by El-debiky Co., Cairo, Egypt. Its purity was found to be $100.48 \% \pm 0.84$ according to the official HPLC method. ${ }^{1}$

- Labipress plus ${ }^{\circledR}$ tablets produced by El-debiky Pharmaceutical Company, Cairo, Egypt: Batch No: (141019). Each tablet is labeled to contain $100 \mathrm{mg}$ of labetalol hydrochloride and $25 \mathrm{mg}$ of hydrochlorothiazide.

\section{3. Chemicals and Reagents}

All chemicals and reagents used were obtained from Sigma Aldrich.

-2-hydroxypropyl- $\beta$-cyclodextrin ( $\beta C)$, tetrahydrofuran (THF), and ammonium reineckate (RNC)

- polyvinyl chloride (PVC), tributyl phthalate (TBP), and dioctyl phthalate (DOP)

- deionized water

- potassium chloride $(\mathrm{KCl})$

\section{4. Standard Solutions}

- Standard stock solution $\left(10^{-2} \mathrm{M}\right)$ was prepared by dissolving $364.87 \mathrm{mg}$ of Lab in $100 \mathrm{ml}$ deionized water.

- Serial dilutions from the stock solution were made in deionized water to prepare $\left(10^{-7} \mathrm{M}-10^{-3} \mathrm{M}\right)$ working standard solutions of Lab.

\section{5. Procedures}

\section{5. 1. Preparation of Membrane Sensors}

\section{(a) Membrane 1a\&b}

For the preparation of membrane 1a, $0.04 \mathrm{~g} 2$-hydroxypropyl- $\beta$-cyclodextrin was mixed with $0.40 \mathrm{~g}$ of DOP and $0.19 \mathrm{~g}$ of PVC. This mixture was dissolved in 5 $\mathrm{ml}$ THF in a $5 \mathrm{~cm}$ diameter glass petri dish and covered with filter paper to allow for solvent evaporation at room temperature for 24 h. $0.1 \mathrm{~mm}$ thickness master membrane was obtained and used for the construction of the electrode. Membrane $1 \mathrm{~b}$ was prepared similarly but with the use of TBP instead of DOP.

\section{(b) Membrane $2 a \& b$}

For the preparation of membrane $2 \mathrm{a}, 0.01 \mathrm{~g}$ ammonium reineckate (RNC) was mixed with $0.40 \mathrm{~g}$ of DOP and $0.19 \mathrm{~g}$ of PVC. This mixture was dissolved in $5 \mathrm{ml}$ THF in a $5 \mathrm{~cm}$ diameter glass petri dish and covered with filter paper to allow for solvent evaporation at room temperature for $24 \mathrm{~h} .0 .1 \mathrm{~mm}$ thickness master membrane was obtained and used for the construction of the electrode. Membrane $2 \mathrm{~b}$ was prepared similarly but with the use of TBP instead of DOP.

Disks of about $12 \mathrm{~mm}$ diameter were cut from each master membrane with a cork borer and glued to an interchangeable PVC tip (fixed to the end of an electrode glass body) using THF and left to dry for $24 \mathrm{~h}$. Then the prepared electrodes were filled with equal volumes of $10^{-3} \mathrm{M}$ Lab and $10^{-3} \mathrm{M} \mathrm{KCl}$ as an internal solution and a $1 \mathrm{~mm}$ diameter $\mathrm{Ag} / \mathrm{AgCl}$ wire was used as an internal reference electrode. Electrodes were soaked in $10^{-3} \mathrm{M}$ aqueous solution of Lab for $24 \mathrm{~h}$ for conditioning and kept in the same solution when not in use.

\section{5. 2. Sensors Calibration}

Calibration of conditioned sensors was performed by immersing prepared electrodes, in conjunction with the $\mathrm{Ag} / \mathrm{AgCl}$ reference electrode, into a set of $100 \mathrm{ml}$ beakers containing $50 \mathrm{ml}$ separate aliquots of $\left(10^{-7} \mathrm{M}-10^{-2} \mathrm{M}\right)$ solutions of Lab and allowed to equilibrate under stirring with washing with deionized water between measurements. The potential difference (emf) between each of the prepared membrane sensors (indicator electrode) and $\mathrm{Ag} / \mathrm{AgCl}$ reference electrode was measured and plotted as a function of the negative logarithm of Lab concentration. Regression equations were calculated for the linear part of the curves and used for the estimation of Lab concentrations. 


\section{5. 3. Sensors Selectivity}

Potentiometric selectivity coefficient $\left(K^{\text {Pot. }}\right.$ lab, interferent $)$ was estimated following IUPAC guidelines, ${ }^{27}$ using separate solution method (SSM), ${ }^{26}$ in which the potential of two separate solutions, A (Lab) and B (interfering ion) at a concentration of $10^{-3} \mathrm{M}$, was measured by prepared membrane electrode conjugated with reference electrode.

$$
\begin{aligned}
\log K{ }^{\text {Pot. }}{ }_{\mathrm{A}, \mathrm{B}}= & {\left[\left(E_{\mathrm{B}}-E_{\mathrm{A}}\right) /\left(2.303 \mathrm{R} T / Z_{\mathrm{A}} \mathrm{F}\right)\right]+} \\
& +\left[1-\left(Z_{\mathrm{A}} / Z_{\mathrm{B}}\right] \log [\mathrm{A}]\right.
\end{aligned}
$$

Where $E_{\mathrm{A}}$ is the potential measured in $1 \times 10^{-3} \mathrm{M}$ standard Lab solution, $E_{\mathrm{B}}$ is the potential measured in $1 \times$ $10^{-3} \mathrm{M}$ interfering ion solution, $Z_{\mathrm{A}}$ and $Z_{\mathrm{B}}$ are the charges of Lab and interfering ion, respectively, and $2.303 \mathrm{RT} / \mathrm{Z}_{\mathrm{A}} \mathrm{F}$ represents the slope of the calibration curve.

\section{5. 4. Application to Pharmaceutical Formulations}

Twenty tablets of Labipress plus ${ }^{\circledR}$ tablets were pulverized and the accurate weight of powdered tablets was dissolved in $100 \mathrm{ml}$ deionized water for $15 \mathrm{~min}$ to prepare $10^{-2} \mathrm{M}$ solution of Lab. Prepared sensors, conjugated with $\mathrm{Ag} / \mathrm{AgCl}$ reference electrode, were immersed in the prepared solution. The measured potential was used to estimate the concentration of Lab in solution by substitution in the regression equation of the corresponding electrode.

\section{Results and Discussion}

\section{1. Sensors Preparation}

Ion-selective electrodes' use in quantitative estimation of active drug substances in pharmaceuticals has shown superiority over other analytical techniques because of high selectivity and suitability for the analysis of turbid or colored test solutions over wide ranges of $\mathrm{pH}$ and concentrations with high accuracy and fast response.

In the present work, a cationic type of ion exchangers, 2-hydroxypropyl- $\beta$-cyclodextrin and ammonium reineckate, was used in electrode preparation based on the fact that Lab in aqueous solution behaves as a cation; also, 2 -hydroxypropyl- $\beta$-cyclodextrin and ammonium reineckate are physically compatible with PVC polymeric matrix that was used to produce highly stable complexes as PVC has the advantages of chemical inertness and low cost but its use raises a need for a plasticizer. ${ }^{24}$

Dioctyl phthalate and tributyl phthalate were selected as plasticizers because of their chemical asymmetry that results in unique electrical properties as they allow PVC membranes to operate with less energy input than with other plasticizers, relatively non-volatile under heat and maintain flexibility at low temperature combined with a resistance to high temperature..$^{27}$

\section{2. Sensors Calibration and Response Time}

IUPAC recommendation data ${ }^{28}$ were used for evaluating the electrochemical performance characteristics of proposed sensors, Table 1. Calibration graphs are presented in Fig. 2, showing stability, consistency of potential readings and stability of calibration slopes over 1 month. A fast, stable response was obtained within 10-15 $\mathrm{s}$ for sensors $1 \mathrm{a}, 1 \mathrm{~b}$, and $15-20 \mathrm{~s}$ for sensors $2 \mathrm{a}, 2 \mathrm{~b}$ using concentrations of Lab from $10^{-4} \mathrm{M}-10^{-2} \mathrm{M}$ for estimation of the response time of prepared electrodes. The pro-

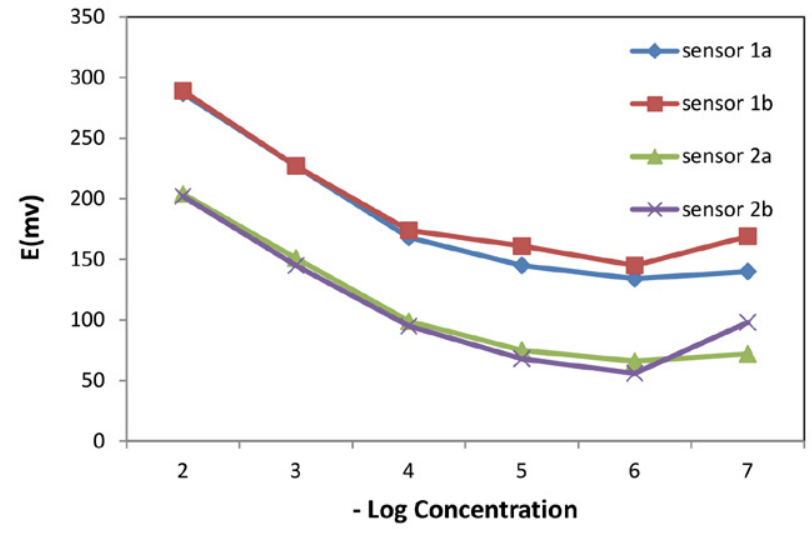

Fig. 2. Profile of the potential in $\mathrm{mV}$ versus - $\log$ (concentration of $\mathrm{Lab}$ ) using the investigated sensors.

\begin{tabular}{|c|c|c|c|c|}
\hline Parameter & Sensor 1a & Sensor $\mathbf{1 b}$ & Sensor $2 a$ & Sensor $\mathbf{2 b}$ \\
\hline Slope (mV/decade) & -59.60 & -57.58 & -53.00 & -55.00 \\
\hline Intercept (mV) & 406.40 & 403.34 & 310.60 & 310.60 \\
\hline Correlation coefficient & 0.9999 & 0.9997 & 0.9999 & 0.9999 \\
\hline Response time (s) & $10-15$ & $10-15$ & $15-20$ & $15-20$ \\
\hline Working $\mathrm{pH}$ range & $2.00-5.10$ & $2.00-5.10$ & $2.00-5.10$ & $2.00-5.10$ \\
\hline Concentration range $(\mathrm{M})$ & $10^{-4}-10^{-2}$ & $10^{-4}-10^{-2}$ & $10^{-4}-10^{-2}$ & $10^{-4}-10^{-2}$ \\
\hline Life span (weeks) & $2-4$ & $2-4$ & $2-3$ & $2-3$ \\
\hline Average recovery ${ }^{\mathrm{a}} \pm \mathrm{SD}$ & $100.12 \pm 0.27$ & $99.74 \pm 0.35$ & $99.83 \pm 0.25$ & $99.87 \pm 0.52$ \\
\hline $\operatorname{LOD}(\mathrm{M})$ & $4.17 \times 10^{-5}$ & $3.98 \times 10^{-5}$ & $3.98 \times 10^{-5}$ & $3.16 \times 10^{-5}$ \\
\hline
\end{tabular}

Table 1. Response characteristics of the investigated sensors.

average of three determinations 
posed sensors displayed good long term potential stability for 2-4 weeks.

\section{3. Effect of $\mathrm{pH}$ and Temperature}

Conditions affecting the response of ion-selective electrodes were studied to determine the optimum conditions for quantitative measurement. The effect of $\mathrm{pH}$ was

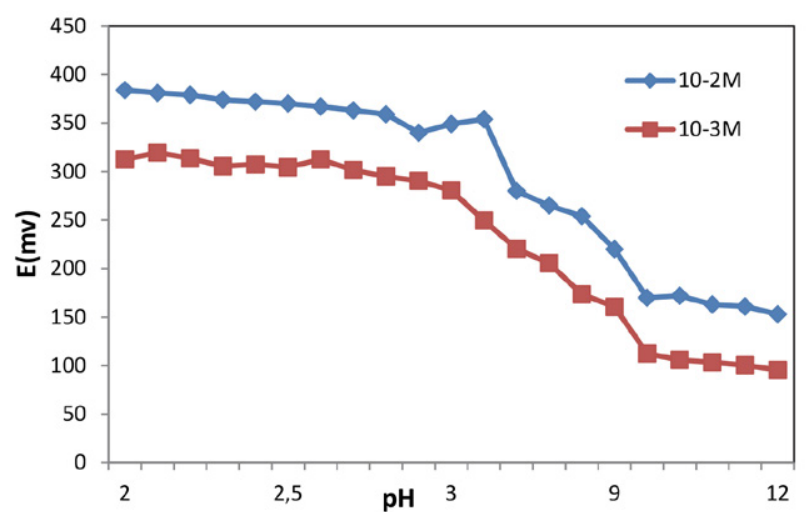

Fig. 3. Effect of $\mathrm{pH}$ on the response of $\mathrm{Lab}$ sensor 1a

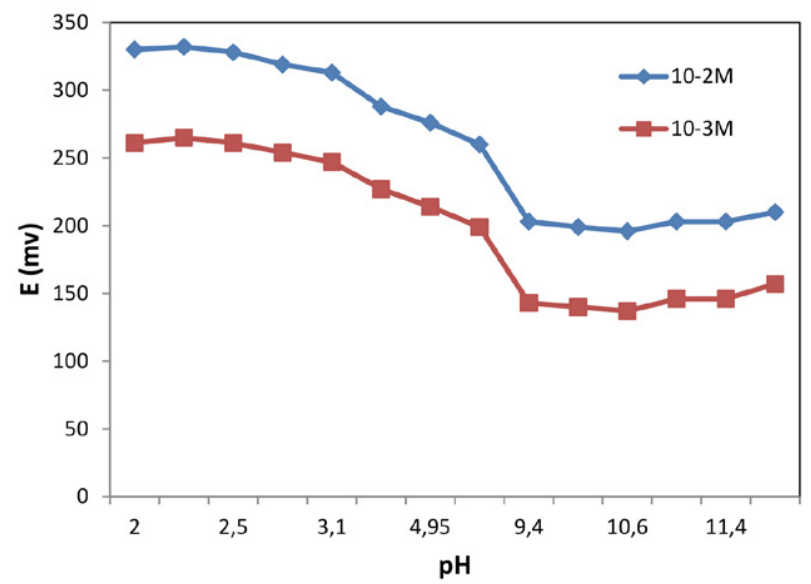

Fig. 4. Effect of $\mathrm{pH}$ on the response of Lab sensor $1 \mathrm{~b}$

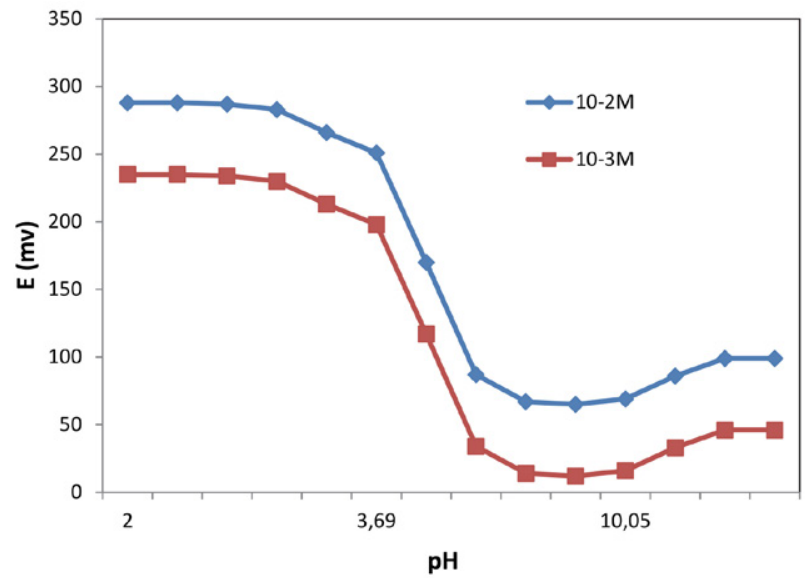

Fig. 5. Effect of $\mathrm{pH}$ on the response of Lab sensor 2a studied considering both sensor function and chemical form of Lab. It was concluded from Fig. 3-6, that sensors response is fairly steady over $\mathrm{pH}$ range $2.00-5.10$ where $\mathrm{Lab}$ exists in the cationic form and is detectable by the electrodes; outside this $\mathrm{pH}$ range, the potentials measured by the electrodes were unstable. The temperature effect was also studied, where the proposed membrane sensors

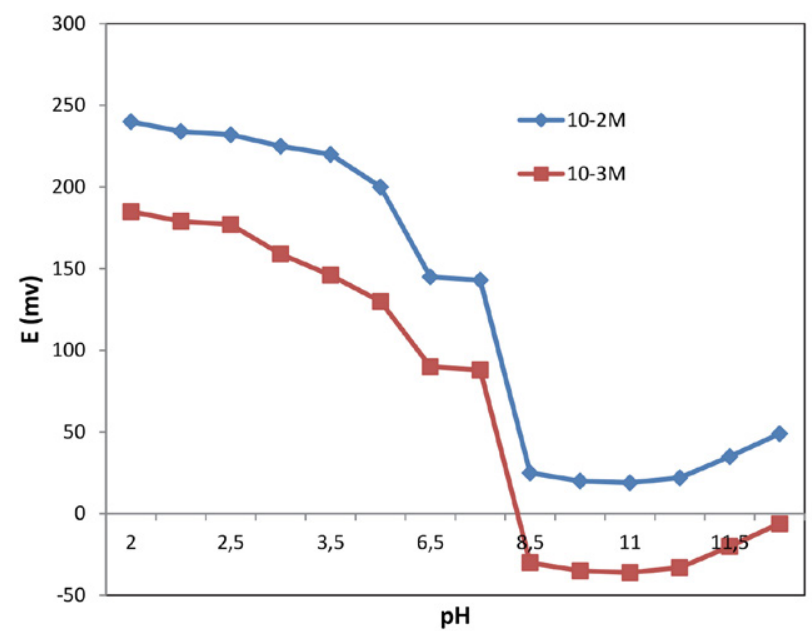

Fig. 6. Effect of $\mathrm{pH}$ on the response of Lab sensor $2 \mathrm{~b}$

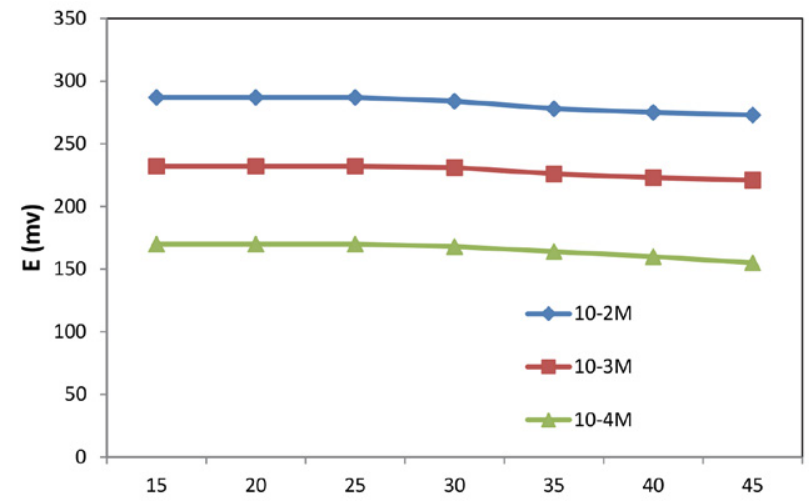

Fig. 7. Effect of temperature on the response of Lab sensor 1a

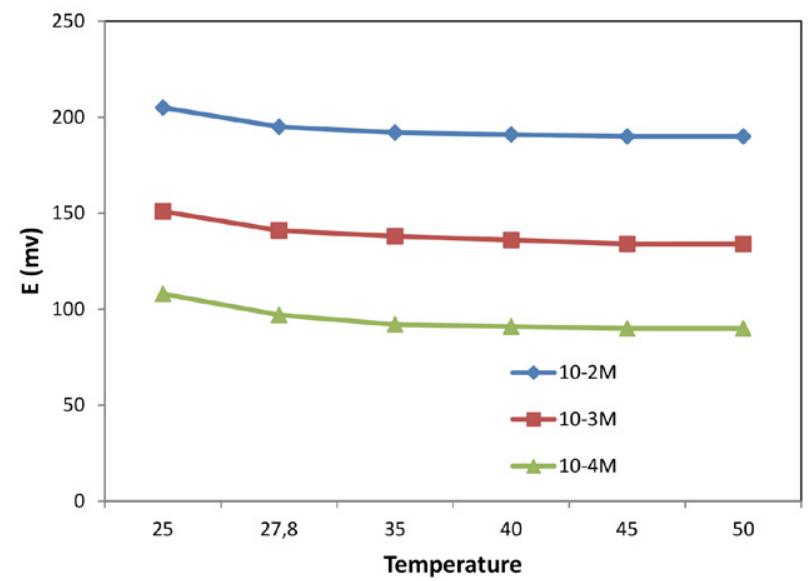

Fig. 8. Effect of temperature on the response of Lab sensor $1 \mathrm{~b}$ 


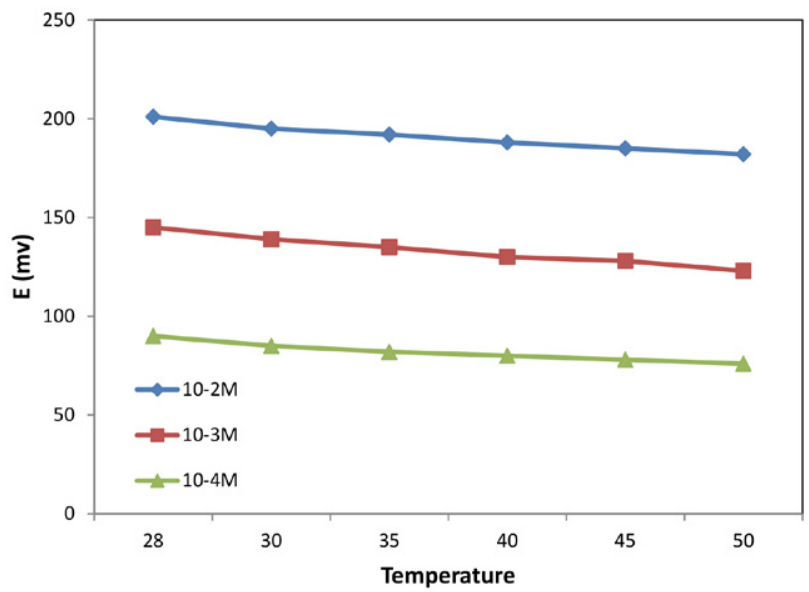

Fig. 9. Effect of temperature on the response of Lab sensor 2a

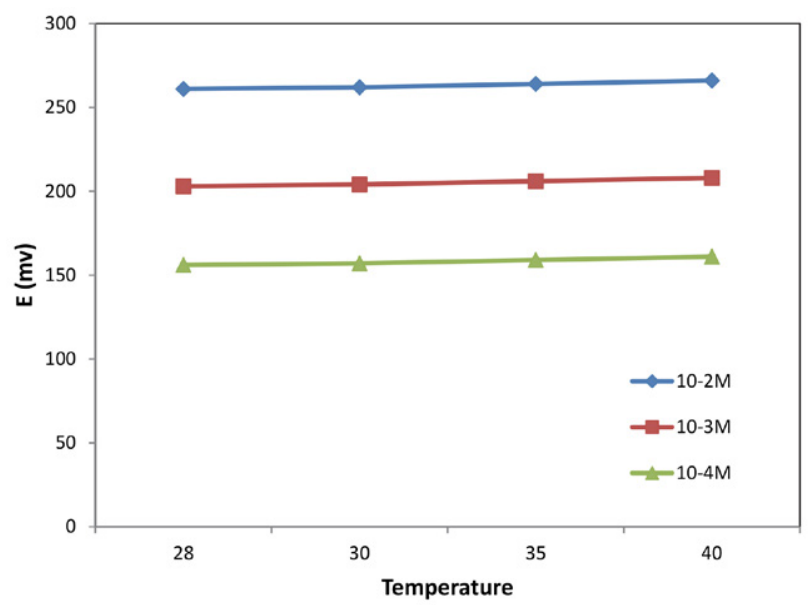

Fig. 10. Effect of temperature on the response of Lab sensor $2 b$

displayed thermal stability up to $35{ }^{\circ} \mathrm{C}$ indicated by a steady potential response, Fig. 7-10.

\section{4. Sensors Selectivity}

The potentiometric selectivity coefficient was determined for several excipients, co-administered drugs, and related substances by the proposed sensors. Table 2: the results revealed high selectivity for Lab and that no significant interference was observed.

\section{5. Application to Pharmaceutical Formulations}

The proposed sensors were used for determination of Lab in Labipress plus ${ }^{\circledR}$ tablets without pretreatment and no interference was observed from excipients or hydrochlorothiazide as a co-formulated drug, Table 3.

No remarkable difference was detected upon the statistical comparison between results of the proposed electrodes and the official method, ${ }^{1}$ for determination of the pure form of Lab, Table 4.

\section{6. Application to Biological Fluids}

Trials were made to use the proposed sensors for determination of Lab in biological fluids since Lab is absorbed rapidly after oral administration with peak plasma concentration achieved within $2 \mathrm{~h}$ and its bioavailability varies from $10 \%$ to over $80 \%$ correlating with age. But also approximately $50 \%$ of Lab is bound to the plasma proteins which prevented direct determination of Lab in human plasma using proposed sensors. ${ }^{29} \mathrm{Lab}$ is eliminated mainly by hepatic metabolism with the production of several biologically inactive glucuronides which in turn are excreted in the urine and bile. Approximately $85 \%$ of Lab in the blood is removed during a single passage through the liver which also prevented its determination in human urine using proposed sensors. ${ }^{29}$

\section{Conclusion}

The described sensors displayed fast, selective and accurate potential response for Lab over concentration range $\left(10^{-4} \mathrm{M}-10^{-2} \mathrm{M}\right)$ and have equal efficiency to previously developed methods ${ }^{10,18}$ used for quantitative estima-

Table 2. Potentiometric selectivity coefficients of the proposed electrodes using a separate solution method.

\begin{tabular}{lcccr}
\hline \multirow{2}{*}{ Interferents $^{\text {a }}$} & \multicolumn{2}{c}{ Selectivity Coefficient } \\
& Sensor 1a & Sensor 1b & Sensor 2a & Sensor 2b \\
\hline Hydrochlorothiazide & $3.26 \times 10^{-5}$ & $5.62 \times 10^{-5}$ & $2.76 \times 10^{-5}$ & $4.42 \times 10^{-5}$ \\
Chlorothiazide & $1.76 \times 10^{-4}$ & $4.54 \times 10^{-4}$ & $2.49 \times 10^{-5}$ & $3.95 \times 10^{-5}$ \\
Benzothiadiazine & $1.59 \times 10^{-5}$ & $3.90 \times 10^{-5}$ & $2.06 \times 10^{-5}$ & $3.17 \times 10^{-5}$ \\
$\mathrm{KCl}$ & $1.90 \times 10^{-4}$ & $3.68 \times 10^{-4}$ & $2.19 \times 10^{-5}$ & $6.31 \times 10^{-5}$ \\
$\mathrm{NaCl}$ & $1.83 \times 10^{-4}$ & $4.49 \times 10^{-4}$ & $3.37 \times 10^{-5}$ & $7.31 \times 10^{-5}$ \\
$\mathrm{CuSO}_{4}$ & $1.31 \times 10^{-3}$ & $3.23 \times 10^{-3}$ & $2.14 \times 10^{-3}$ & $3.66 \times 10^{-3}$ \\
Lactose $_{\mathrm{Ammonium} \text { dihydrogen phosphate }}$ & $1.63 \times 10^{-4}$ & $4.08 \times 10^{-4}$ & $2.48 \times 10^{-4}$ & $2.14 \times 10^{-4}$ \\
$\mathrm{CaCO}_{3}$ & $8.28 \times 10^{-3}$ & $9.06 \times 10^{-3}$ & $8.92 \times 10^{-3}$ & $5.92 \times 10^{-3}$ \\
Starch $^{-3}$ & $4.87 \times 10^{-4}$ & $3.93 \times 10^{-4}$ & $5.11 \times 10^{-4}$ & $1.43 \times 10^{-6}$ \\
\hline
\end{tabular}

${ }^{\mathrm{a} A q u e o u s ~ S o l u t i o n s ~ o f ~} 1 \times 10^{-3} \mathrm{M}$ were used 
Table 3. Determination of Lab in Labipress plus ${ }^{\circledR}$ tablets by the proposed sensors

\begin{tabular}{|c|c|c|c|c|c|}
\hline \multirow{2}{*}{ Preparation } & \multirow{2}{*}{ Company method ${ }^{b}$} & \multicolumn{4}{|c|}{ Sensors } \\
\hline & & Sensor 1a & Sensor $\mathbf{1 b}$ & Sensor $2 a$ & Sensor $2 b$ \\
\hline Labipress Plus tablets & Found $^{\mathrm{a}}$ & Assay & Assay & Assay & Assay \\
\hline $\begin{array}{l}\text { Each tablet contains } \\
100 \mathrm{mg} \text { labetalol } \mathrm{HCl} \text {, }\end{array}$ & $\pm \mathrm{RD}$ & Found $^{\mathrm{a}} \pm \mathrm{RD}$ & Found $^{\mathrm{a}} \pm \mathrm{RD}$ & Found $^{\mathrm{a}} \pm \mathrm{RD}$ & Found $^{\mathrm{a}} \pm \mathrm{RD}$ \\
\hline $\begin{array}{l}25 \mathrm{mg} \text { hydrochlorothiazide } \\
\text { B.N.: } 141019\end{array}$ & $99.91 \pm 0.91$ & $99.96 \pm 0.89$ & $99.70 \pm 1.34$ & $99.90 \pm 0.84$ & $99.20 \pm 0.58$ \\
\hline
\end{tabular}

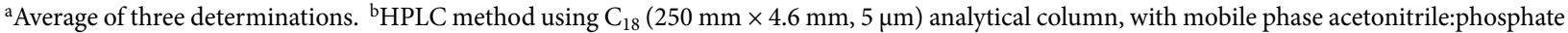
buffer $(\mathrm{pH}=3.5)$ :triethylamine in ratio $(40: 60: 0.1 \mathrm{v} / \mathrm{v} / \mathrm{v})$ with flow rate $1.0 \mathrm{ml} / \mathrm{min}$ at $230 \mathrm{~nm}$.

Table 4. Statistical comparison of results obtained by the proposed sensors and the official method for determination of Lab in pure form.

\begin{tabular}{lccccc}
\hline Items & Offical method $^{\mathbf{1}}$ & sensor 1a & sensor 1b & sensor 2a & sensor 2b \\
\hline Mean $^{\mathrm{a}}$ & 100.48 & 100.12 & 99.74 & 99.83 & 99.87 \\
S.D & 0.84 & 0.27 & 0.35 & 0.25 & 0.52 \\
Variance & 0.71 & 0.07 & 0.12 & 0.06 & 0.27 \\
n & 5 & 3 & 3 & 3 & 3 \\
S.E & 0.38 & 0.16 & 0.20 & 0.14 & 0.30 \\
$t$-test (2.447) & - & 0.87 & 1.72 & 1.81 & 1.26 \\
F-ratio (19.25) & - & 10.14 & 5.92 & 11.83 & 2.63 \\
\hline
\end{tabular}

${ }^{a}$ Official HPLC method using $\mathrm{C}_{18}(200 \mathrm{~mm} \times 4.6 \mathrm{~mm}, 5 \mu \mathrm{m})$ analytical column, with mobile phase methanol:phosphate buffer in the ratio $(35: 65 \mathrm{v} / \mathrm{v})$ with flow rate $1.5 \mathrm{ml} / \mathrm{min}, 60^{\circ} \mathrm{C}$ at $230 \mathrm{~nm} \cdot{ }^{1 \mathrm{~s}}$

tion of Lab in pure and combined pharmaceutical formulation and more, they are eco-friendly, require minimum preparations for test measurement and show long term stability in response which suggests their use for quality control purpose as proposed electrodes enable determination of Lab over concentration range that covers its concentration in pharmaceutical formulation with reasonable sensitivity and are easily fabricated in comparison to other membranes. ${ }^{30}$

\section{References}

1. The United States Pharmacopoeia (USP 40), National Formulary (NF 35), the United States Pharmacopoeial Convention, Rockville, MD, USA. 2017

2. A. M. Sambrook, R. C. Small, Anaesth. Intens. Care Med. 2008, 9, 128-131. DOI:10.1016/j.mpaic.2008.01.008

3. A. S. Joel, N. Shantaram, C. Naresh, Int. J. Res. Pharm. Biomed. Sci. 2013, 4, 380-384.

DOI:10.13179/canchemtrans.2013.01.01.0014

4. P. Lukkari, T. Nyman, M. L. Riekkola, J. Chromatogr. A. 1994, 674, 241-246. DOI:10.1016/0021-9673(94)85229-4

5. D. R. EL-Wasseef, S. M. EL-Ashry, M. A. ABU-EL-Enein, M. A. A. Moustafa. J. Food Drug. Anal. 2006, 14, 133-140.

DOI: $10.6227 /$ jfda

6. F. Belal, S. Al-Shaboury, A. S. Al-Tamrah, J. Pharm. Biomed. Anal.2002, 30, 1191-1196.

DOI:10.1016/S0731-7085(02)00471-5
7. N. Rahman, S. K. Haque, Int. J. Biomed. Anal.2008, 4, 140146.

8. N.Rahman, S.K.Haque, S. M. Hossain, Can.Chem. Trans.2013, 1(1), 66-77. DOI:10.13179/canchemtrans.2013.01.01.0014

9. K. V. Raju, N. Annapurna, D. A. R. Babu, T. S. L. Kethurah, J. Chem. Pharm. Res. 2015, 7(6),399-405

10. M. Y. Salem, N. Y. Hassan, Y. Fayez, S. Abd-Elsabour, E. S. Ali, J. Curr. Pharm. Anal. 2018.

DOI:10.2174/1573412914666180716161557

11. A. Witek, H. Hopkala, G. Matysik, Chromatographia. 1999, 50, 41-44. DOI:10.1007/BF02493615

12. H. Zhao, H. Li, Z. Qiu, Chin. J. Chromatogr, 1999, 17, 369371. DOI:10.1046/j.1365-2397.1999.00005.x

13. C. Ceniceros, M. I. Maguregui, R. M. Jimenez, R. M. Alonso, J. Chromatogr. B, 1998, 705, 97-103.

DOI:10.1016/S0378-4347(97)00492-1

14. M. Delamoye, C. Duvernewil, F. Paraire, P. de Mazancourt, J. C. Alvarez, Int. Foren. Sci, 2004, 141, 23-31.

DOI:10.1016/j.forsciint.2003.12.008

15. A. Changchit, J. Gal, J. A. Zirrolli, Biolog. Mass. Spectrum, 1991, 20, 751-758. DOI:10.1002/bms. 1200201202

16. S. Carda-Broch, R. Rapado-Martinez, I. Esteve-Romero, M. C. Garcia-Alverez-Coque, J .Chromatogr. Sci, 1999, 37, $93-$ 102. DOI:10.1093/chromsci/37.4.93

17. C. Karlsson, H. Wikstrom, D. D. Armstrong, P. K. Owens, J. Chromatogr. A, 2000, 897, 349-363.

DOI:10.1016/S0021-9673(00)00805-0

18. M. Y. Salem, N. Y. Hassan, Y. Fayez, S. Abd-Elsabour, E. S. Ali, J. Iran. Chem. Soci. 2019. 
DOI: org/10.1007/s13738-019-01593-7

19. T. V. Goel, J. G. Nikelly, R. C. Simpson, B. K. Matuszewski, J. Chromatogr. A, 2004, 1027, 213-221.

DOI:10.1016/j.chroma.2003.08.082

20. S. L. Tamisier-Karolak, M. A. Stenger, A. Bommart, Electrophoresis, 1999, 20, 2656-2663. DOI:10.1002/(SICI)1522-2683 (19990901)20:13<2656::AID-ELPS2656>3.0.CO;2-6

21. S. Jana, P. Jozef, J .Chromatogr. A, 1996, 735, 403-408. DOI:10.1016/0021-9673(95)00722-9

22. M. A. Iorio, A. Mazzeo-Farina, A. Doldo, J. Pharm. Biomed. Anal, 1987, 5, 1-10. DOI:10.1016/0731-7085(87)80002-X

23. E. Gorodkiewicz, P. Falkowski, A. Sankiewicz, Z. Figaszewski, Central Euro. J. Chem. 2003, 1, 242-259.

DOI:10.2478/BF02476227

24. A. Radi, Z. El-Sherif, A. Wassel, Chem. Papers, 2004, 58, 242-246.
25. A. M. El-Kosasy, M. Nebsen, M. K. Abd El-Rahman, M. Y. Salem, M. G. El-Bardicy, Talanta, 2011, 85 (2),913-918.

DOI:10.1016/j.talanta.2011.04.071

26. S. S. Hassan, W. H. Mahmoud, A. H. M. Othman, Analytica. Chim. Acta, 1996, 322, 39-48.

DOI:10.1016/0003-2670(96)00223-1

27. J. Murphy, Additives for Plastics Handbook, $2^{\text {nd }} E d, 2001$.

28. IUPAC Analytical Chemistry Division, Pure Appl. Chem. 2000, 72, 1851.

29. J. J. McNeil, W. J.Louis, Clin Pharmacokinet,1984,9(2),157-67. DOI:10.2165/00003088-198409020-00003

30. J. Gallardo-Gonzalez, A. Saini, A. Baraket, S. Boudjaoui, A. Alcacer,A. Streklas, F. Teixidor, N. Zine, J. Bausells, A. Errachid, Sens. Actuators. B.,2018, 266, 823-829.

DOI:10.1016/j.snb.2018.04.001

\section{Povzetek}

Članek opisuje uporabo elektrokemijske tehnike za določanje labetalol hidroklorida (Lab) v čisti obliki in v kombiniranih farmacevtskih pripravkih z namenom kontrole kakovosti. Razvili smo štiri membranske senzorje na osnovi dveh plastifikatorjev, dioktil ftalata z 2-hidroksipropil- $\beta$-ciklodekstrinom in amonijevim reinekatom (RNC) za senzorja 1a in $2 \mathrm{a}$, ter tributil ftalata $\mathrm{z}$ 2-hidroksipropil- $\beta$-ciklodekstrinom in amonijevim reinekatom za senzorja $1 \mathrm{~b}$ in $2 \mathrm{~b}$, ki služita kot ionoforja v matrici polivinil klorida (PVC). Za vse senzorje smo znotraj koncentracijskega območja $10^{-4} \mathrm{M}-10^{-2} \mathrm{M}$ in pH-območja 2,00-5,10 ugotovili hiter odgovor in stabilen Nernstov naklon 59,60 mV/dekado za 1a, 57,58 mV/dekado za 2a, 53,00 mV/dekado za 1 b in $55,00 \mathrm{mV} /$ dekado za 2b. Razviti senzorji so pokazali dobro selektivnost za Lab v čisti obliki in v prisotnosti drugih zdravil, mnogih interferenčnih ionov ter polnil, prisotnih v farmacevtskih pripravkih. Pri statistični primerjavi rezultatov, dobljenih s predlaganimi senzorji in $\mathrm{z}$ uradno metodo, nismo ugotovili znatnih razlik.

Except when otherwise noted, articles in this journal are published under the terms and conditions of the Creative Commons Attribution 4.0 International License 